The University of Maine

\title{
DigitalCommons@UMaine
}

Earth Science Faculty Scholarship

Earth Sciences

2-1-2009

\section{Chevkinite-Group Minerals from Granulite-Facies Metamorphic Rocks and Associated Pegmatites of East Antarctica and South India}

\author{
H. E. Belkin \\ R. Macdonald \\ Edward S. Grew \\ University of Maine - Main, esgrew@maine.edu
}

Follow this and additional works at: https://digitalcommons.library.umaine.edu/ers_facpub

Part of the Earth Sciences Commons

\section{Repository Citation}

Belkin, H. E.; Macdonald, R.; and Grew, Edward S., "Chevkinite-Group Minerals from Granulite-Facies Metamorphic Rocks and Associated Pegmatites of East Antarctica and South India" (2009). Earth Science Faculty Scholarship. 23.

https://digitalcommons.library.umaine.edu/ers_facpub/23 


\title{
Chevkinite-group minerals from
} granulite-facies metamorphic rocks

\section{and associated pegmatites of East Antarctica and South India}

\author{
H. E. BelKin ${ }^{1, *}$, R. MACDONALD ${ }^{2,3}$ AND E. S. GRew ${ }^{4}$ \\ ${ }^{1}$ U.S. Geological Survey, 956 National Center, Reston, VA 20192, USA \\ ${ }^{2}$ IGMiP Faculty of Geology, University of Warsaw, Al. Żwirki i Wigury 93, 02-089 Warsaw, Poland \\ ${ }^{3}$ Environment Centre, Lancaster University, Lancaster LA1 4YQ, UK \\ ${ }^{4}$ Department of Earth Sciences, University of Maine, 5790 Bryand Center, Orono, ME 04469, USA
}

[Received 17 December 2008; Accepted 22 April 2009]

\section{ABSTRACT}

Electron microprobe data are presented for chevkinite-group minerals from granulite-facies rocks and associated pegmatites of the Napier Complex and Mawson Station charnockite in East Antarctica and from the Eastern Ghats, South India. Their compositions conform to the general formula for this group, viz. $A_{4} B C_{2} D_{2} \mathrm{Si}_{4} \mathrm{O}_{22}$ where, in the analysed specimens $A=$ (rare-earth elements (REE), Ca, Y, Th), $B=$ $\mathrm{Fe}^{2+}, \mathrm{Mg}, C=\left(\mathrm{Al}, \mathrm{Mg}, \mathrm{Ti}, \mathrm{Fe}^{2+}, \mathrm{Fe}^{3+}, \mathrm{Zr}\right)$ and $D=\mathrm{Ti}$ and plot within the perrierite field of the total $\mathrm{Fe}$ (as $\mathrm{FeO}$ ) (wt.\%) vs. $\mathrm{CaO}$ (wt.\%) discriminator diagram of Macdonald and Belkin (2002). In contrast to most chevkinite-group minerals, the $A$ site shows unusual enrichment in the MREE and HREE relative to the LREE and $\mathrm{Ca}$. In one sample from the Napier Complex, $\mathrm{Y}$ is the dominant cation among the total $R E E+\mathrm{Y}$ in the $A$ site, the first reported case of Y-dominance in the chevkinite group. The minerals include the most Al-rich yet reported in the chevkinite group ( $\leqslant 9.15 \mathrm{wt} . \% \mathrm{Al}_{2} \mathrm{O}_{3}$ ), sufficient to fill the $C$ site in two samples. Conversely, the amount of Ti in these samples does not fill the $D$ site, and, thus, some of the $\mathrm{Al}$ could be making up the deficiency at $D$, a situation not previously reported in the chevkinite group. Fe abundances are low, requiring $\mathrm{Mg}$ to occupy up to $45 \%$ of the $B$ site. The chevkinite-group minerals analysed originated from three distinct parageneses: (1) pegmatites containing hornblende and orthopyroxene or garnet; (2) orthopyroxene-bearing gneiss and granulite; (3) highly aluminous paragneisses in which the associated minerals are relatively magnesian or aluminous. Chevkinite-group minerals from the first two parageneses have relatively high $\mathrm{FeO}$ content and low $\mathrm{MgO}$ and $\mathrm{Al}_{2} \mathrm{O}_{3}$ contents; their compositions plot in the field for mafic and intermediate igneous rocks. In contrast, chevkinite-group minerals from the third paragenesis are notably more aluminous and have greater $\mathrm{Mg} / \mathrm{Fe}$ ratios.

KEYWORDs: chevkinite-group, perrierite, Antarctica, Eastern Ghats, India.

\section{Introduction}

THE most abundant members of the chevkinite group (Table 1), chevkinite-(Ce) and perrierite(Ce), are found in igneous rocks ranging from gabbros to peralkaline granites, and in fenites, ore

* E-mail: hbelkin@usgs.gov

DOI: $10.1180 /$ minmag.2009.073.1.149 deposits, granulite-facies gneisses and metacarbonates. In terms of crystal structure, these two minerals are dimorphs (e.g. Bonatti and Gottardi, 1966; Sokolova et al., 2004), but chemical data show that they are compositionally distinct; chevkinites tend to have greater total $\mathrm{Fe}$ $\left(\mathrm{FeO}^{*}=\right.$ total iron as $\left.\mathrm{Fe}^{2+}\right)$ and $\mathrm{Ce}_{2} \mathrm{O}_{3}$ and smaller $\mathrm{CaO}$ and $\mathrm{Al}_{2} \mathrm{O}_{3}$ than perrierites (e.g. van Bergen, 1984; Macdonald and Belkin, 2002).

In a review of compositional variation in minerals of the chevkinite group, Macdonald 
TABle 1. Possible end-members in the chevkinite group, $A_{4} B C_{2} D_{2} \mathrm{Si}_{4} \mathrm{O}_{22}$.

\begin{tabular}{lcl}
\hline End-member & Chevkinite subgroup & \multicolumn{1}{c}{ Perrierite subgroup } \\
\hline $\mathrm{Ce}_{4} \mathrm{Fe}^{2+}\left(\mathrm{Fe}_{2}^{3+}\right) \mathrm{Ti}_{2} \mathrm{Si}_{4} \mathrm{O}_{22}$ & Chevkinite-(Ce), Maoniupingite-(Ce) & Perrierite-(Ce) in part \\
$\mathrm{Ce}_{4} \mathrm{Fe}^{2+}\left(\mathrm{Fe}^{2+} \mathrm{Ti}_{2}\right) \mathrm{Ti}_{2} \mathrm{Si}_{4} \mathrm{O}_{22}$ & Dingdaohengite-(Ce) & Perrierite-(Ce) in part \\
$\mathrm{Ca}_{4} \mathrm{Ti}_{2}\left(\mathrm{Ti}_{2}\right) \mathrm{Ti}_{2} \mathrm{Si}_{4} \mathrm{O}_{22}$ & In maoniupingite-(Ce) & Ca-analogue of matsubaraite \\
$\mathrm{Sr}_{4} \mathrm{Ti}_{2}\left(\mathrm{Ti}_{2}\right) \mathrm{Ti}_{2} \mathrm{Si}_{4} \mathrm{O}_{22}$ & Matsubaraite \\
$\mathrm{Sr}_{4} \mathrm{Zr}_{2}\left(\mathrm{Ti}_{2}\right) \mathrm{Ti}_{2} \mathrm{Si}_{4} \mathrm{O}_{22}$ & & Rengeite \\
$\mathrm{Ca}_{4} \mathrm{Zr}_{2}\left(\mathrm{Ti}_{2}\right) \mathrm{Ti}_{2} \mathrm{Si}_{4} \mathrm{O}_{22}$ & & Ca-analogue of rengeite \\
$\mathrm{Ce}_{4} \mathrm{Zr}_{2}\left(\mathrm{Fe}_{2}^{2+}\right) \mathrm{Ti}_{2} \mathrm{Si}_{4} \mathrm{O}_{22}$ & & In strontio-chevkinite \\
$\mathrm{Ce}_{4} \mathrm{Mg}\left(\mathrm{Cr}_{2}^{3+}\right) \mathrm{Ti}_{2} \mathrm{Si}_{4} \mathrm{O}_{22}$ & & Mg, Al analogue of perrierite-(Ce) \\
$\mathrm{Ce}_{4} \mathrm{Mg}\left(\mathrm{Al}_{2}\right) \mathrm{Ti}_{2} \mathrm{Si}_{4} \mathrm{O}_{22}$ & Polyakovite-(Ce) & Al analogue of perrierite-(Ce) \\
$\mathrm{Ce}_{4} \mathrm{Fe}^{2+}\left(\mathrm{Al}_{2}\right) \mathrm{Ti}_{2} \mathrm{Si}_{4} \mathrm{O}_{22}$ & & \\
& & \\
\hline
\end{tabular}

Names accepted by the CNMNC IMA are in bold. Subgroups implied by the dimorphism of chevkinite-(Ce) and perrierite-(Ce) (Sokolova et al., 2004).

and Belkin (2002) suggested that further compositional variants, or even new species, might be found in parageneses unusual for the group, such as high-grade metamorphic rocks. They also called for further analyses of perrierite, which is less-well documented than chevkinite. Compared to chevkinite, relatively few compositions plotting in the perrierite field of Macdonald and Belkin (2002) have been reported since 2002, e.g. Zr-rich perrierite from Peru (Carlier and Lorand, 2008) and a Sc-bearing perrierite from Inner Mongolia, China (Shimazaki et al., 2008). In this paper, we present electron microprobe analyses of chevkinite-group minerals in granulites and associated pegmatites from East Antarctica and South India, with the specific aim of furthering our knowledge of the compositional range of minerals in the group.

The results also brought to light nomenclature problems in the chevkinite group. New species have been approved on an ad hoc basis with little attempt to choose which crystallographic sites should serve as criteria for distinguishing species, as has been done for other complex mineral groups, most recently the sapphirine group (Grew et al., 2008). In view of the potentially chaotic situation in chevkinite-group nomenclature and for want of a better term, we will refer to our minerals simply as 'chevkinite-group minerals'.

\section{Source of the samples}

Beginning with the reports by Atrashenok et al. (1967) and Kamenev (1972) of a 'metasomatic chevkinite' from a fissure in charnockite of the
Archaean Napier Complex, Enderby Land, Antarctica (Fig. 1), minerals of the chevkinite group have been reported from several localities in Antarctica, including Napier granulite-facies rocks (Grew and Manton, 1979a; Hokada, 2007), the Mawson Station charnockite (Grew and Manton, 1979b), and a partially melted sapphirine granulite xenolith in norite in the Vestfold Hills, $\sim 600 \mathrm{~km}$ east of Mawson Station (Harley, 1994). Grew and Manton (1986) also reported perrierite from a sapphirine-bearing migmatite in the Eastern Ghats Province, South India. Only the Vestfold Hills and Mt. Riiser-Larsen (Napier Complex) samples were completely analysed; the others were used for isotopic dating for which only $\mathrm{Th}, \mathrm{U}$ and $\mathrm{Pb}$ contents are needed. The present paper reports data on the chevkinitegroup minerals studied by Grew and Manton, together with a few samples from nearby localities, i.e. five samples from four localities (Mt. Charles, Mt. Cronus, Zircon Point, Fyfe Hills) in the Napier Complex, Enderby Land, East Antarctica, one from the Mawson Station charnockite, MacRobertson Land, East Antarctica, and four (3080P, R, T, U) from Anakapalle in the Eastern Ghats Province of South India (Fig. 1).

\section{Geological background}

Rocks exposed along the periphery of East Antarctica between $45^{\circ} \mathrm{E}$ and $65^{\circ} \mathrm{E}$ belong to the Archaean Napier Complex and Proterozoic Rayner Complex, both granulite-facies complexes with long histories extending from $\sim 3800$ to 


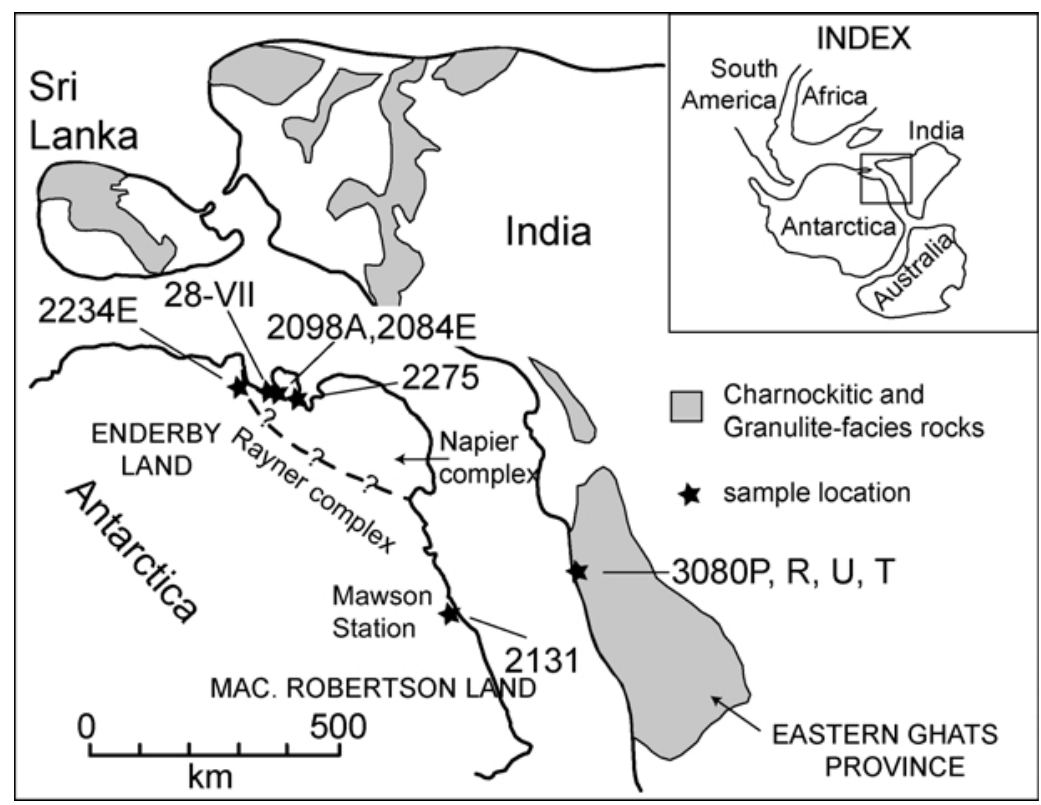

FIG. 1. Locality map; details of the individual samples can be found in the text (simplified from Grew and Manton, 1986).

$\sim 500 \mathrm{Ma}$ (e.g. Grew and Manton, 1979a; Sheraton et al., 1987; Halpin et al., 2005). Four of our samples (28-VII, 2084E, 2234E, 2275) and that studied by Hokada (2007) are granulites from the southwestern part of the complex, where metamorphic temperatures are estimated to have reached $1070^{\circ} \mathrm{C}$ and pressures of $7-10 \mathrm{kbar}$ (e.g. Harley, 1998, 2008). Sample 2098A is from a pegmatite vein at Mt. Charles, also in the southwestern part of the complex. The vein was emplaced at $\sim 2500 \mathrm{Ma}$ and conditions of crystallization were earlier estimated to be as high as $1000-1100^{\circ} \mathrm{C}$ at $9-11 \mathrm{kbar}$ (Grew et al., 2000). Although the vein probably crystallized at very high temperatures, the $1000-1100^{\circ} \mathrm{C}$ estimate might be too high because veins of this generation were emplaced after the peak of ultrahightemperature metamorphism (Grew et al., 2006). Sample 2131 is from a pegmatite dated at $850 \mathrm{Ma}$ (Grew and Manton, 1979b) that cuts one of the Mawson charnockites, a group of Rayner Complex hypersthene adamellites, quartz monzodiorites and granodiorites emplaced soon after peak metamorphism and dated at 985-954 Ma (e.g. Sheraton, 1982; Young and Black, 1991; Young et al., 1997; Halpin et al., 2005).

The Eastern Ghats Province probably represents an extension of the late Proterozoic Rayner
Complex into India (Grew and Manton, 1979a, 1986). Our samples are sapphirine-bearing migmatites from near Anakapalle, possibly an Archaean or early Proterozoic rock (age $\geqslant 2000 \mathrm{Ma}$ ), reworked during late Proterozoic metamorphism at $1000 \mathrm{Ma}$ (Grew and Manton, 1986). Like the Napier Complex, the Eastern Ghats belt is an ultrahigh-temperature complex, metamorphosed under conditions of 7-10 kbar, 900 to $>1000^{\circ} \mathrm{C}$ (e.g. Sengupta et al., 1999; Bose et al., 2000; Sarkar et al., 2003).

\section{Sample descriptions}

\section{E}

Sample 2234 is a garnet-biotite-sillimanite quartzo-feldspathic granulite from the Napier Complex at Zircon Point in Casey Bay (Grew et al., 2006). Sapphirine occurs only as inclusions in garnet. The chevkinite-group mineral is optically isotropic (metamict) and forms an aggregate several $\mathrm{mm}$ across with quartz and garnet adjacent to a garnet porphyroblast (Fig. 2a). The mineral encloses sillimanite, and is also found enclosed in garnet and sapphirine, textural relationships suggesting that the mineral crystallized over a time interval including the metamorphic peak. One subhedral $2 \mathrm{~mm}$ crystal has been analysed. 

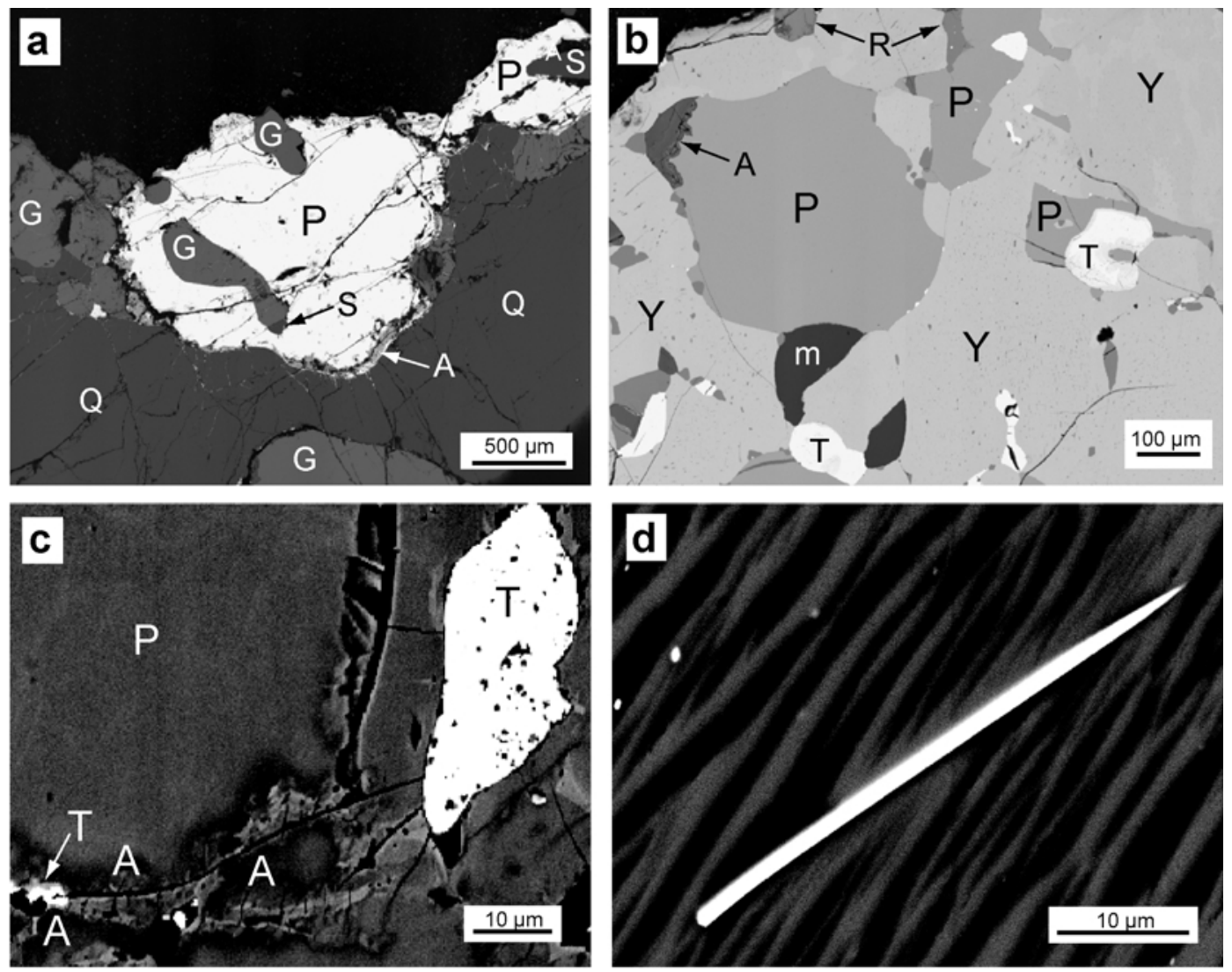

FIG. 2. SEM-BSE images of varying contrasts showing the textural settings and mineral associations of the Antarctic and Indian chevkinite-group minerals. (a) Millimetre-size grain of a chevkinite-group mineral (P) from sample 2234E along the edge of a thin section with inclusions of garnet $(\mathrm{G})$ and sillimanite $(\mathrm{S})$ in a quartz $(\mathrm{Q})$ and garnet $(\mathrm{G})$ assemblage. An irregular altered (A) rim around the chevkinite-group mineral is somewhat depleted in $R E E$. (b) Anhedral grains of a chevkinite-group mineral (P) from sample 2275 enclosed by yttrium titanoniobate (Y) with biotite $(\mathrm{m})$, rutile $(\mathrm{R})$ and altered and unaltered thorite $(\mathrm{T})$. The chevkinite-group mineral is altered (A) along fractures. (c) A portion of a large grain of a chevkinite-group mineral (P) from sample 2098A that has been somewhat altered (A) along fractures in which thorite (T) has precipitated. (d) Acicular chevkinite-group mineral in mesoperthite from sample 3080T.

\section{5 - Mt. Cronus, Napier Complex}

This is a light-grey, fine-grained, orthopyroxene-garnet-biotite-bearing, quartzo-feldspathic gneiss (Asami et al., 1998, 2002). Plagioclase, containing abundant antiperthitic lamellae, is the dominant phase. Other phases include rutile, an ore mineral and zircon. A redbrown to olive, optically isotropic (metamict) yttrium titanoniobate, possibly polycrase, occurs as rounded to ellipsoidal aggregates $0.2-0.7 \mathrm{~mm}$ across, commonly enclosed in garnet. The chevkinite-group mineral forms $100-500 \mu \mathrm{m}$, light-brown, rounded, metamict grains enclosed in the polycrase (?), which also includes thorite (Fig. 2b); these relationships suggest that the mineral crystallized at close to metamorphic peak conditions. Some outer portions of the mineral are altered; our analyses come from the higher $\bar{Z}(\bar{Z}=$ mean atomic number), unaltered area in six grains.

\section{A}

The chevkinite-group mineral in 2098A forms an optically isotropic (metamict) mass $\sim 5 \mathrm{~cm}$ across in a pegmatite cutting orthopyroxenebearing quartzo-feldspathic gneisses of the 
Napier Complex at Mt. Charles (Grew and Manton, 1979a; Grew, 1998; Grew et al., 2000). Essential constituents of the pegmatite are quartz, perthite, antiperthite, orthopyroxene, hornblende mantled by orthopyroxene-plagioclase symplectite, and zircon; the chevkinite-group mineral appears also to be a primary pegmatite phase; it contains thorite and altered thorite in slightlyaltered areas defined by fractures (Fig. 2c); both slightly altered and unaltered areas were analysed. This mineral was identified as 'perrierite' by Grew and Manton (1979a) using X-ray diffraction (XRD) of metamict material reconstituted by heating at $700-1000^{\circ} \mathrm{C}$ in air or in a reducing atmosphere, an approach suggested by Lima-deFaria (1962).

\section{E - Napier Complex}

This specimen is from a quartzo-feldspathic gneiss containing minor orthopyroxene and trace garnet, biotite, zircon, allanite and a chevkinitegroup mineral from a second locality on Mt. Charles. Allanite and the mineral, generally found adjacent to orthopyroxene, are optically active. Acicular $250 \mu \mathrm{m}$ and elongate $200 \mu \mathrm{m}$ grains were analysed.

\section{$28-\mathrm{VII}$}

This is a medium-grained, quartzo-feldspathic granulite from the Napier Complex at the Fyfe Hills (DePaolo et al., 1982). Whole-rock analysis gives a metaluminous composition, with 0.2 normative diopside. The dominant phases reported by these authors are plagioclase $(66 \%$ modal), K-feldspar (15\%), quartz (12\%) and orthopyroxene $(5 \%)$, with $1 \%$ each opaque and apatite and trace amounts of hornblende, biotite, chlorite, zircon, monazite and a chevkinite-group mineral. The last forms rare, brown, isotropic, metamict grains. A $60 \mu \mathrm{m}$ slightly altered grain was analysed.

\section{$2 / 31$}

This pegmatite from Mawson Station, MacRobertson Land, Antarctica contains quartz, feldspar, garnet, apatite, hornblende, biotite, zircon and a chevkinite-group mineral (Grew and Manton, 1979b). The last is metamict, dark brown and translucent only in thin slivers. Four $10-40 \mu \mathrm{m}$ grains in allanite were analysed.

Textures in 2084E, 28-VII, and 2131 do not preclude a high-temperature origin for the chevkinite-group mineral in these samples, but they are not sufficiently definitive for us to draw conclusions about the timing of crystallization of this mineral.

\section{P, $R, U$ and $T$}

Samples 3080P, $R$ and $U$ are from the same quarry, north of Anakapalle (Grew, 1982), as is sample 3080T described by Grew and Manton (1986). Like 3080T, samples 3080P, R and U are feldspathic layers or diffuse, cross-cutting pegmatitic veinlets, both forms typical of migmatitic sapphirine granulites at Anakapalle. These rocks are dominated by mesoperthitic feldspar up to several centimetres across, with subordinate quartz and orthopyroxene, and local garnet, biotite, sillimanite, sapphirine, zircon, monazite and a chevkinite-group mineral. The last forms pleochroic grains up to $0.1 \mathrm{~mm}$ long in garnet and in association with sillimanite, sapphirine, biotite and rutile and also occurs as uncommon acicular crystals in mesoperthite (Fig. 2d). It also forms nearly isotropic (metamict) grains several millimetres across. Textures suggest that the chevkinite-group mineral crystallized coevally with sapphirine and garnet (Grew and Manton, 1986).

3080P - anhedral, subhedral and rounded grains, from 10 to $200 \mu \mathrm{m}$ in size - analysed.

$3080 \mathrm{R}$ - anhedral grains ranging in size from $30 \mu \mathrm{m}$ to $2 \mathrm{~mm}$ - analysed.

$3080 \mathrm{U}$ - sub- to anhedral grains ranging in size from 10 to $70 \mu \mathrm{m}$ - analysed.

$3080 \mathrm{~T}$ - subhedral grains and euhedral blades, from 10 to $70 \mu \mathrm{m}$ - analysed.

\section{Analytical methods}

Quantitative analyses of major and minor elements were made using the equipment and techniques described by Macdonald and Belkin (2002). The relative accuracy is $1-2 \%$ for oxide concentrations, $>1 \mathrm{wt} . \%$ and $5-10 \%$ for oxide concentrations $<1$ wt. $\%$. Minor element detection limits are as follows: $\mathrm{Pb}=800 \mathrm{ppm}$; $\mathrm{Gd}, \mathrm{Dy}, \mathrm{Sm}$ and $\mathrm{Pr}=400 \mathrm{ppm} ; \mathrm{Hf}$ and $\mathrm{Ta}=300 \mathrm{ppm} ; \mathrm{Sr}, \mathrm{Nb}$, $\mathrm{Nd}, \mathrm{Tb}$, and $\mathrm{Yb}=200 \mathrm{ppm}$; and all other elements at $\sim 100 \mathrm{ppm}$. Sodium and $\mathrm{U}$ were not detected in any sample.

Unit-cell formulae were calculated on the basis of 22 oxygens, and all $\mathrm{Fe}$ was assumed to be $\mathrm{Fe}^{2+}$. Following the method used by Parodi et al. (1994), Song et al. (1999) and Macdonald and Belkin (2002), cations were allocated to sites as follows: (1) the rare-earth elements $(R E E), \mathrm{Ca}, \mathrm{Sr}$, $\mathrm{Na}, \mathrm{Ba}, \mathrm{K}, \mathrm{Pb}$ and Th enter the $A$ site; (2) the $B$ 
site is filled to 1 in the order $\mathrm{Fe}^{2+} \pm \mathrm{Mn} \pm \mathrm{Mg}$; (3) Ti fills the $D$ site to a maximum of 2; (4) the tetrahedral sites are filled firstly by $\mathrm{Si}$ and, if necessary, made to 4 with $\mathrm{Al} \pm \mathrm{Ti}$. The remaining $\mathrm{Fe}^{2+}, \mathrm{Ti}, \mathrm{Al}, \mathrm{Mn}$ and $\mathrm{Mg}$ enter the $C$ site, along with $\mathrm{Zr}, \mathrm{Nb}$ and $\mathrm{Ta}$.

Representative analyses are given in Table 2; the full data set of 122 analyses is deposited with the Principal Editor of Mineralogical Magazine and is available on-line at: www.minersoc.org/ pages/e_journals/dep_mat_mm.html.

In most of the newly analysed samples (Table 2 and Supplementary Table), total oxides vary between $98 \%$ and $101 \%$. However, in some grains within samples $3080 \mathrm{P}$ and 2084E, analytical totals are between 96 and 98 wt.\%. We suggest that these grains may have been secondarily hydrated, as has been suspected for metamict samples from Virginia and Mali by Macdonald and Belkin (2002). The cation sum varies from $12.9-13.2$, close to the theoretical value of 13 . The sum of cations in the $A$ site (theoretically 4 ) is in the range 3.8 to 4.0 and in the $C$ site 1.9 to 2.1 (theoretically 2). We believe, therefore, that our analyses are essentially complete with $\mathrm{Fe}^{3+}$ much subordinate to $\mathrm{Fe}^{2+}$ and that and that the minerals are close to being stoichiometric.

Haggerty and Mariano (1983) suggested that the $\beta$ angle is the most reliable way of distinguishing chevkinite $\left(100^{\circ}\right)$ from perrierite $\left(113^{\circ}\right)$. However, Macdonald and Belkin (2002) were unable to detect any compositional differences between chevkinites and perrierites classified using $\beta$ angles and those classified on the basis of powder XRD for which the full chemical data sets had not been published and/or structurally refined. Grew and Manton (1979a) identified Antarctic phases as perrierite on this basis. The Antarctic and Eastern Ghats minerals also plot in the perrierite field in the discriminator diagram of Macdonald and Belkin (2002) (Fig. 3).

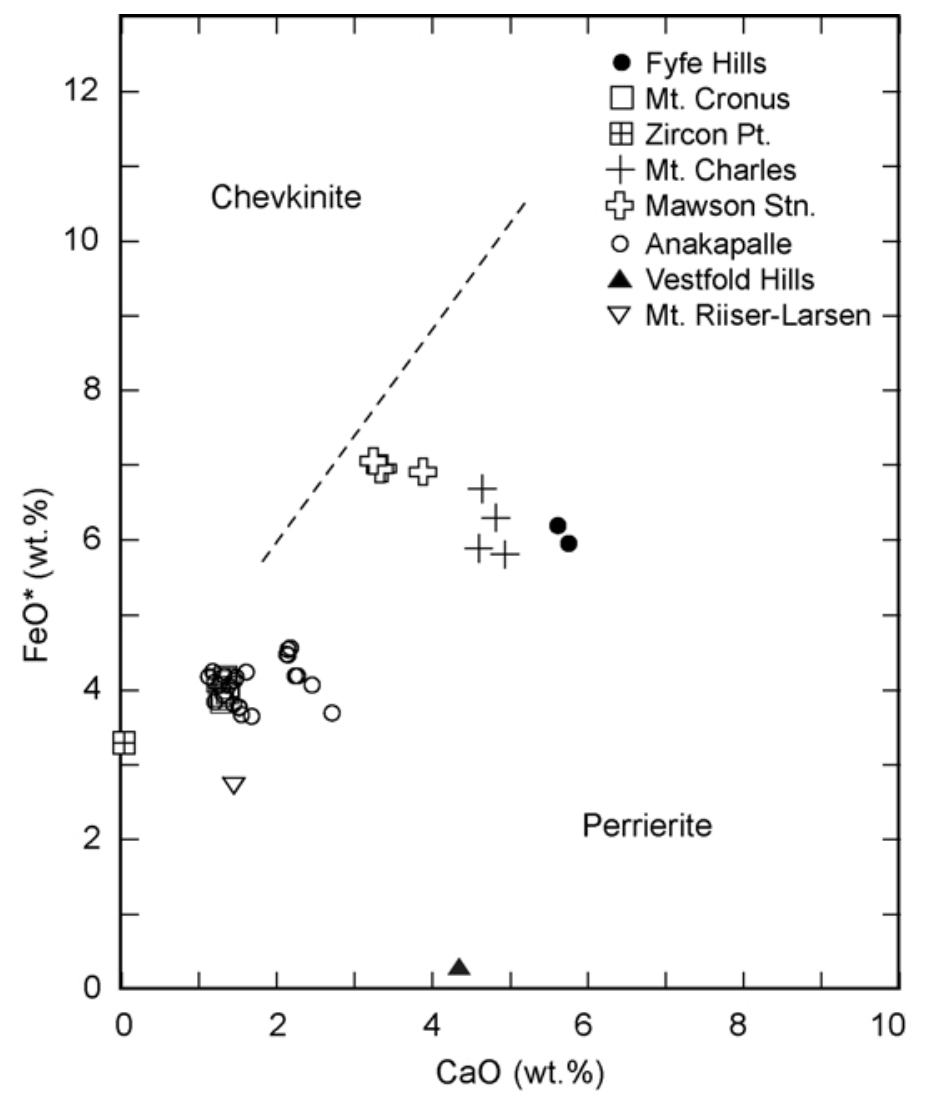

FIG. 3. Antarctic and Eastern Ghats chevkinite-group minerals plotted on the $\mathrm{CaO}-\mathrm{FeO} *$ discriminator of Macdonald and Belkin (2002). 


\section{$F-K \alpha-C e-M \zeta$ interference}

Fluorine concentrations were determined in the studied perrierites by the electron microprobe routine described in Macdonald and Belkin (2002). Examination of the data revealed a high correlation between $\mathrm{Ce}$ and $\mathrm{F}$ abundance when $\mathrm{Ce}_{2} \mathrm{O}_{3}>10 \mathrm{wt} . \%$. This suggested a relationship that did not have a crystallochemical basis but which may have been the result of peak interference. Following up on the suggestion by Martin Yates (pers. comm., 2005), we investigated the interference between F- $K \alpha(\lambda=18.3199 \AA)$ and $\mathrm{Ce}-M \zeta(\lambda=18.3499 \AA)$. Ce- $M \zeta$ intensity relative to the strongest $\mathrm{Ce}-M$ line, $\mathrm{Ce}-M \alpha$, is calculated to be $\mathrm{I}=1$ to 10,000 (Johnson and White, 1970), i.e. within the background of F-K $\alpha$ measured with a W/Si LDE1 diffraction crystal $(2 d=80 \AA)$ supplied by JEOL USA, Inc for a mineral with the high $\mathrm{Ce}$ content characteristic of perrierite. Using the LDE1 crystal with a P10 flow detector, we measured $\mathrm{Ce}-M \zeta$ intensity relative to $\mathrm{Ce}-\mathrm{M \alpha}$ intensity using F-free synthetic $\mathrm{CeO}_{2}$ and Ce phosphate and $\mathrm{Ce}-\mathrm{M} \alpha / \mathrm{Ce}-M \zeta$ ranged from 4 to 5 . These much lower intensity ratios are consistent with studies of the $M$ spectrum that have found the $M \zeta$ relative intensities to differ greatly from their ideal values (Wendt and Christ, 1985; Crisp,
1991). Thus, we conclude that the $F$ values reported in chevkinite and perrierite determined by electron microprobe measurement are probably in error and represent $\mathrm{Ce}-M \zeta$ interference. We suggest that a systematic F study of chevkinitegroup minerals be undertaken using SIMS or LAICP-MS methods.

\section{Composition of perrierites}

\section{The A site}

Total cations in the $A$ site range between 3.83 and 4.02. The main variation in the Antarctic and Indian chevkinite-group minerals, in common with other members of this group, is the substitution of the $R E E$ for $\mathrm{Ca}$ (Fig. 4). The mineral in sample 2234E (Zircon Point) is unusually Ca-poor compared to perrierite (see also Fig. 3). Macdonald and Belkin (2002) noted that, in chevkinite-group minerals, $(\mathrm{La}+\mathrm{Ce}+\mathrm{Ca})$ normally contribute $>75 \%$ of the $A$ site, i.e. the REE abundances in the group normally are dominated by the $L R E E$, e.g. $\left(\sum \mathrm{La}-\mathrm{Sm}\right) /\left(\Sigma_{\text {total }} R E E\right)=0.97$. However, $(\mathrm{La}+\mathrm{Ce}+\mathrm{Ca})$ exceeds $75 \%$ in only $\sim 10 \%$ of our analyses, the others being between 50 and $75 \%$, with one value at $27 \%$. In $\sim 70 \%$ of our analyses, $(\Sigma \mathrm{La}-\mathrm{Sm}) /\left(\Sigma_{\text {total }} R E E\right)<0.97$, in one case (sample 2275) being as low as 0.57 . The

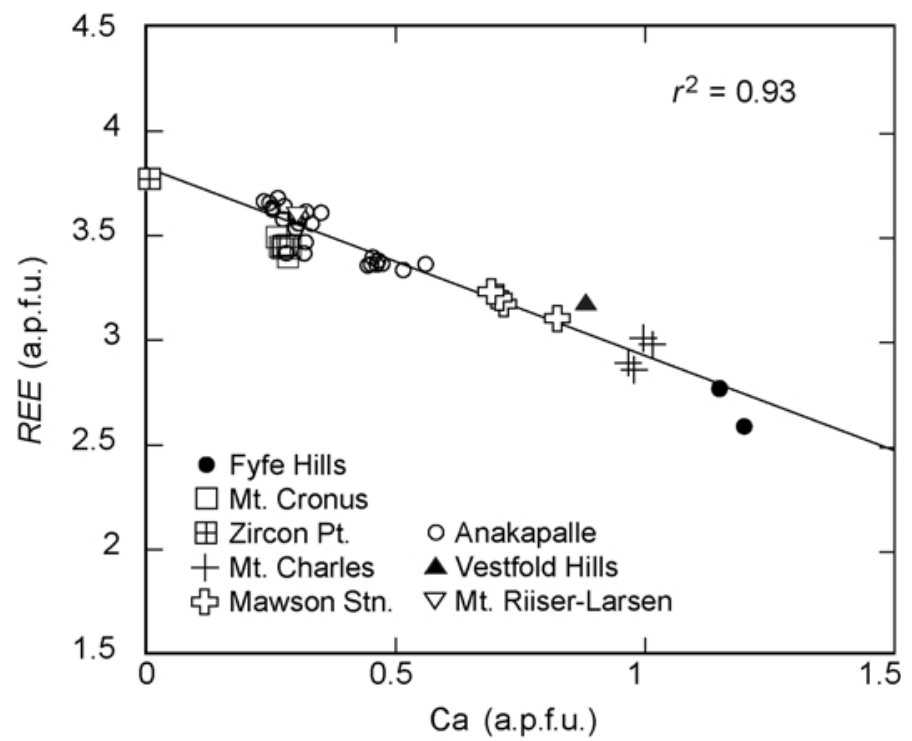

FIG. 4. Relationship between the REE and Ca contents of the Antarctic and Eastern Ghats chevkinite-group minerals. Thorium was not included in this plot. The regression line (slope $=-0.9$ ) is coincident with that determined by Macdonald and Belkin (2002) for chevkinite and perrierite globally; however, the studied data set has a higher regression coefficient reflecting more consistent analytical methods. 
H. E. BELKIN ET AL.

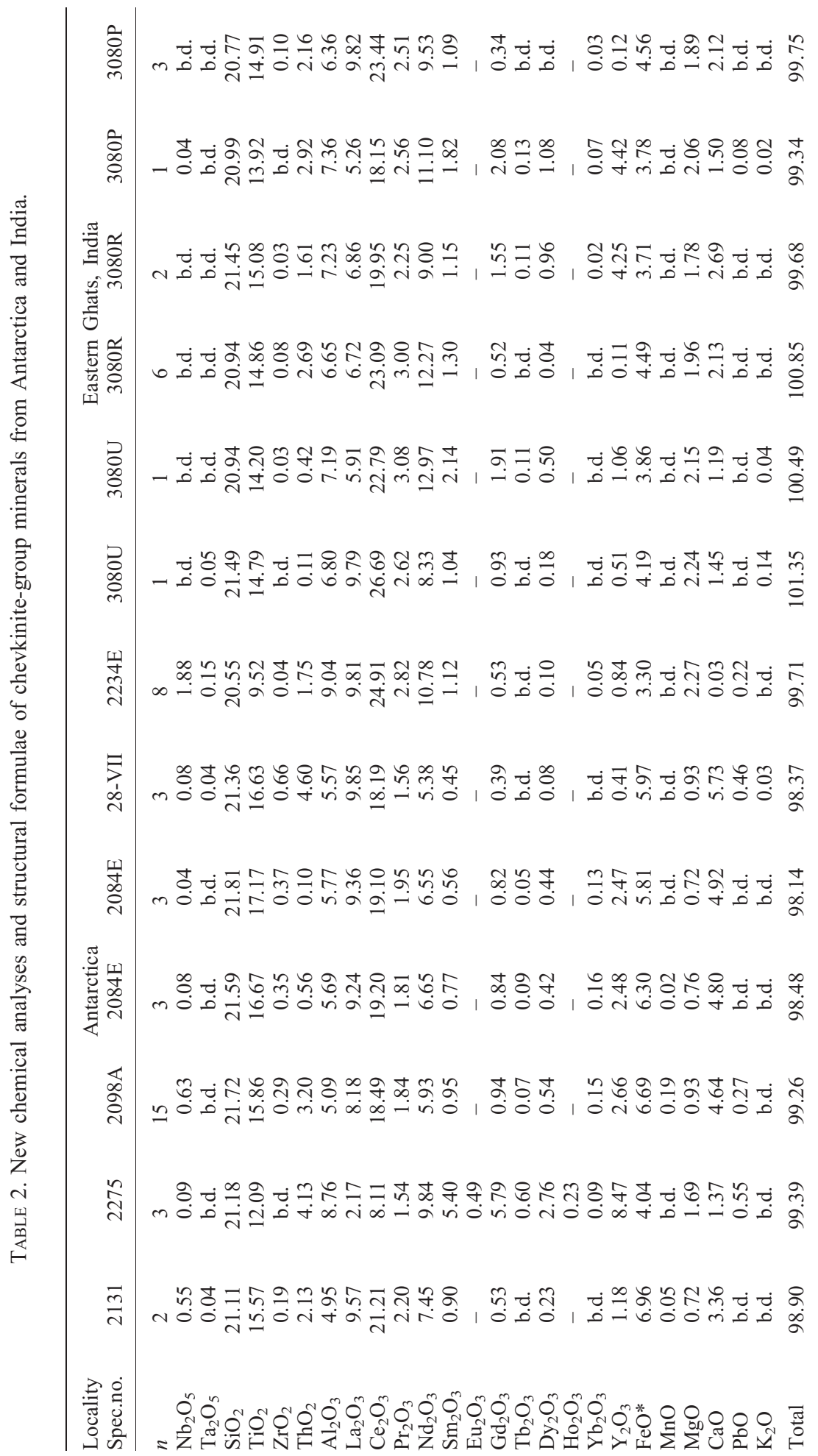




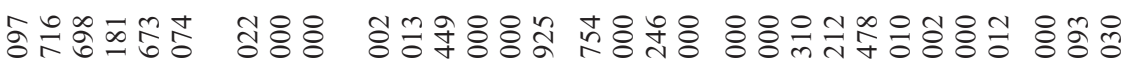

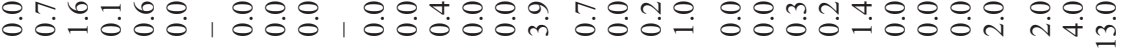

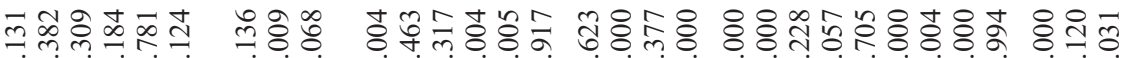

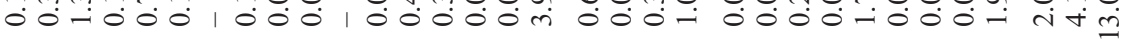

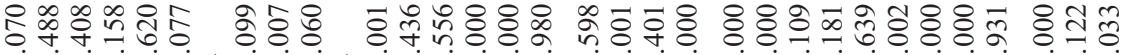

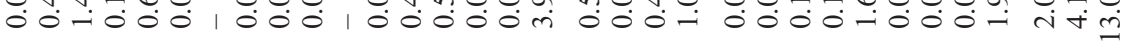

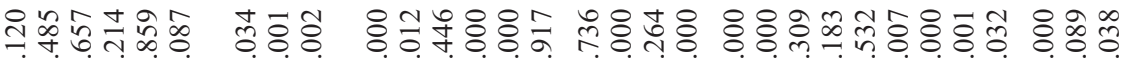

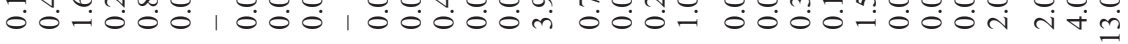

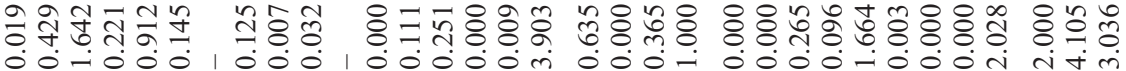

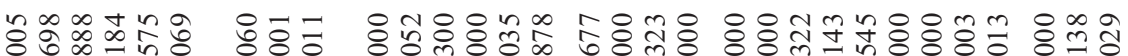
-0.ं00.

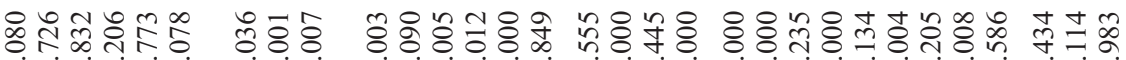

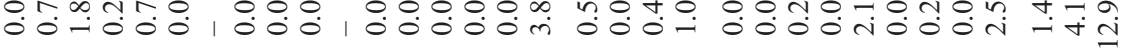

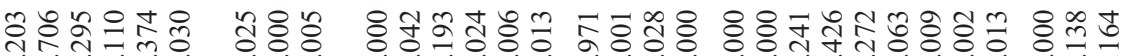

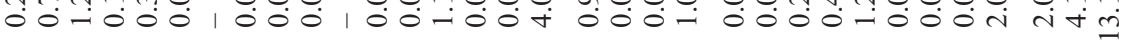

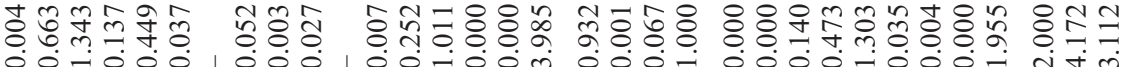

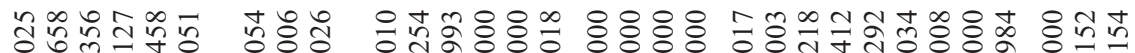

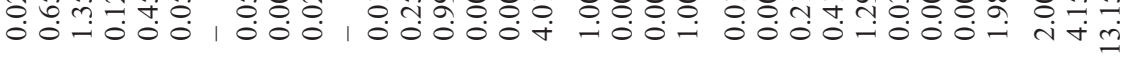

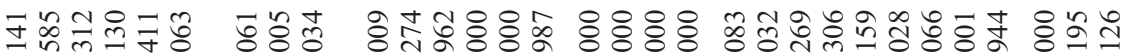
$00.0001000100000 m$-0.

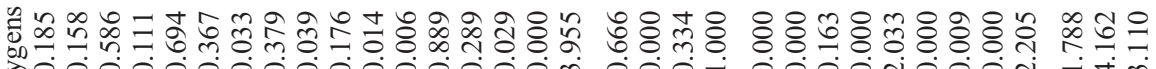

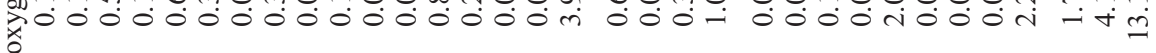
สี

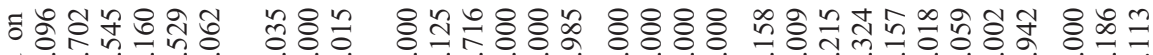

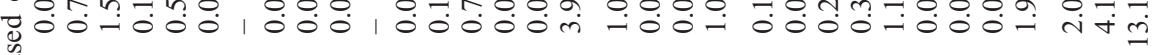
ฮี

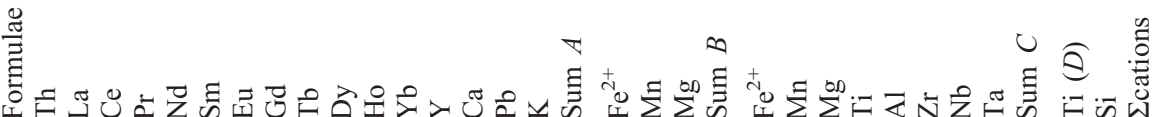

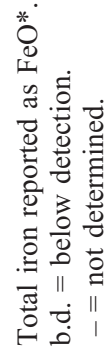




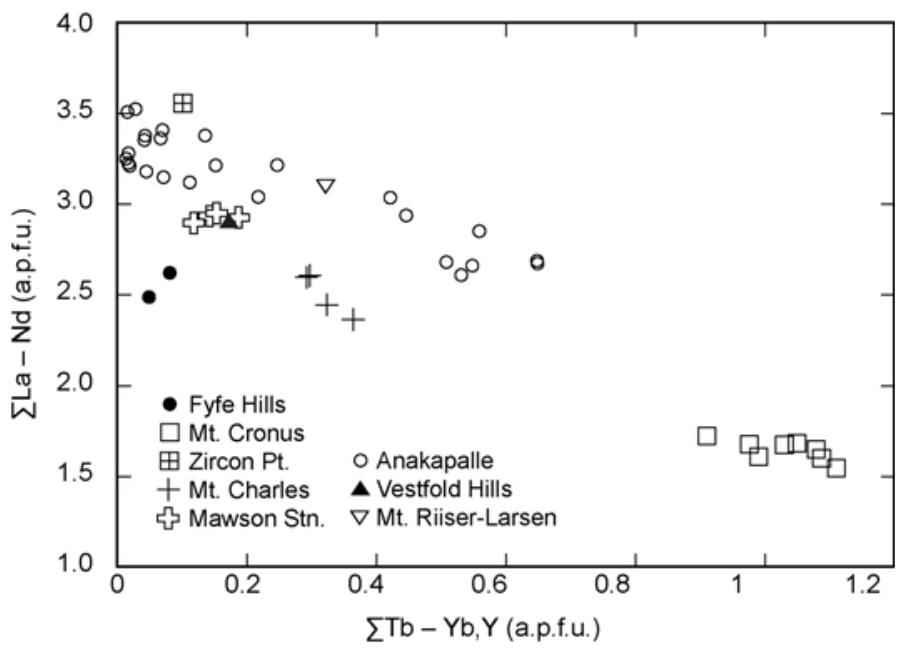

FIG. 5. Relationship between $\operatorname{LREE}(\Sigma \mathrm{La}-\mathrm{Nd})$ and HREE $(\Sigma \mathrm{Tb}-\mathrm{Yb}, \mathrm{Y})$ showing a reciprocal trend. Sample 2275 from Mt. Cronus is the most LREE depleted and HREE enriched and the Anakapalle samples $(3080 \mathrm{R}, \mathrm{U}, \mathrm{P}, \mathrm{T})$ show the greatest variability.

reason for these differences is that compared to perrierite, many of the Antarctic and Eastern Ghats minerals are relatively rich in HREE and $\mathrm{Y}$, especially $\mathrm{Y}$ (up to 8.47 wt. $\% \mathrm{Y}_{2} \mathrm{O}_{3}$, sample 2275 , Mt. Cronus). Indeed, $\mathrm{Y}$ is the dominant cation among the total $R E E+\mathrm{Y}$ in the $A$ site in this sample, the first record of a Y-dominant mineral in the chevkinite group.

In contrast to the considerable variation in LREE abundances reported by Macdonald and Belkin (2002) in chevkinite-group minerals from a wide range of parageneses, the studied minerals show a more limited range; $\mathrm{La} / \mathrm{Ce}$ (atomic) ranges from 0.23 to 0.56 and $\mathrm{La} / \mathrm{Nd}$ ranges from 0.20 to 1.92. $\mathrm{La} / \mathrm{Sm}$ ranges from 2.41 to 47.1 , excluding sample 2275. Sample 2275 (Mt. Cronus) is, on average, the most depleted in $L R E E$ and enriched in MREE, as well as $\mathrm{Y}$ and HREE (Figs 5,6). Figure 5 also shows that Anakapalle samples have the greatest range in LREE/HREE. LREE enrichment dominates the chondrite-normalized rare-earth pattern (Fig. 6) and the slope is similar to chevkinite (Macdonald and Belkin, 2002) but with higher MREE. The scatter shown in HREE (Fig. 6) is in part analytical and argues for further study by the LA-ICP-MS technique.

Apart from $\mathrm{Ca}$ and the $R E E$, the only other notable element in the $A$ site is Th, which can reach up to 0.28 a.p.f.u. Strontium was only detected in about 15 analyses at a level just at or above the detection limit.

\section{The $B$ site}

The $B$ site in chevkinite and perrierite is invariably filled entirely by $\mathrm{Fe}^{2+}$, or in the case of rocks from Mt. Amiata and Sabatini, Italy, by $\mathrm{Fe}^{2+}$ plus much subordinate $\mathrm{Mn} \pm \mathrm{Mg}$ (Macdonald and Belkin, 2002). In a majority of our samples, there is not enough Fe to fill the site and, since Mn is not present in amounts sufficient to make up the difference, $\mathrm{Mg}$ is required in that role, to a maximum of 0.46 a.p.f.u. The chevkinite-group mineral from Mt. Riiser-Larsen, Napier Complex studied by Hokada (2007) is similarly Fe-depleted ( 0.5 a.p.f.u.), but the mineral from the Vestfold Hills has the lowest Fe content reported to date (0.05 a.p.f.u., Harley, 1994). This mineral is one of the two samples with an unfilled $B$ site, $(\mathrm{Mg}=$ 0.78 and $\mathrm{Mn}=0$ a.p.f.u.), the other being a chevkinite from Khibina, Kola Peninsula (Yakovenchuk et al., 2005). However, if $\mathrm{Zr}$ and Hf were assumed to occupy $B$ as $\mathrm{Zr}$ does in rengeite (Miyawaki et al., 2002), then the $B$ occupancy would increase to 0.93 and 1.06 in the Vestfold Hills and Khibiny samples, respectively.

\section{The C site}

Cation sums in the $C$ site are, with two exceptions, within $4 \%$ of the theoretical value of 2. The exceptions are samples 2234E $(\Sigma C=$ 2.586 ) and 2275 (2.205). It may be no coincidence that these samples have, uniquely in our data set, 


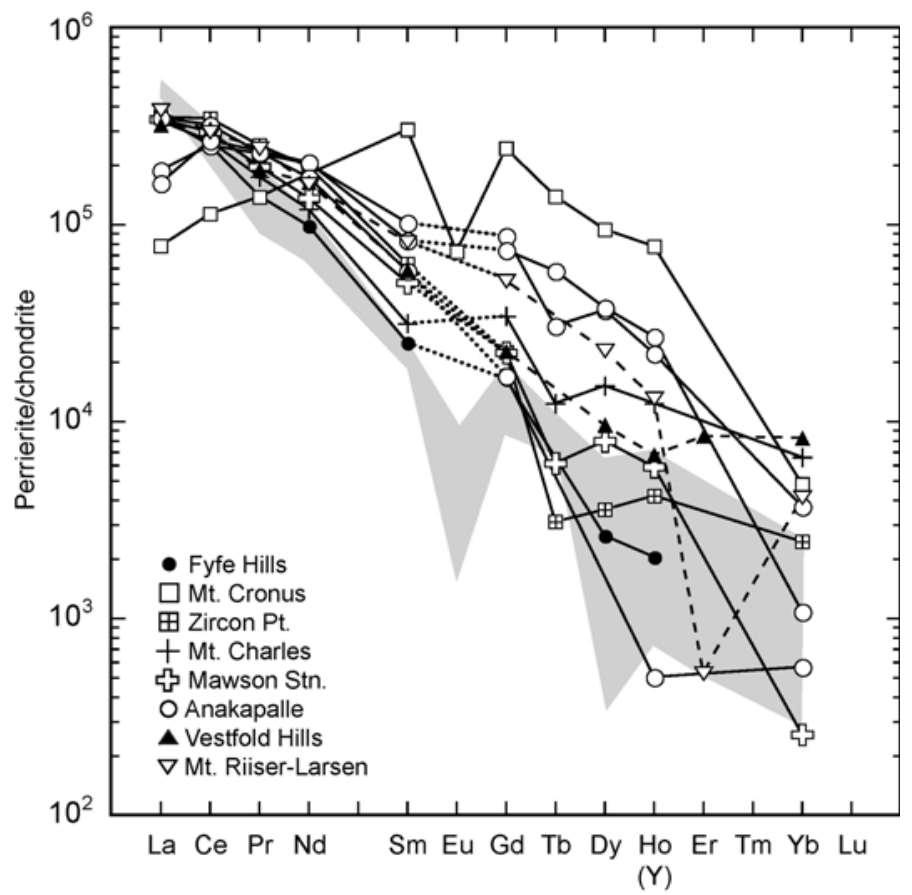

FIG. 6. Chondrite-normalized REE plots for selected chevkinite-group minerals from Antarctica and the Eastern Ghats, to demonstrate (1) the variability in patterns, and (2) the relative MREE and HREE enrichment compared to chevkinites and perrierites from the literature (as exemplified by the shaded field from Macdonald and Belkin, 2002). Yttrium is taken to proxy for Ho in the plot. Patterns dotted between Sm and Gd due to an absence of Eu data. Normalizing factors from Sun and McDonough (1989).

Ti abundances unable to fill the $D$ site $(1.434$ and 1.788 , respectively). This situation, unknown in normal chevkinite and perrierite (Macdonald and Belkin, 2002), raises the possibility that some $\mathrm{Al}$ may enter the $D$ site. In fact, the $C$ site excess is of a sufficient magnitude to compensate for the $\mathrm{Ti}$ (D) site deficiency.

Aluminium is the dominant cation in the $C$ site, and would fill it in the case of samples 2234E and 2275 unless Al makes up the deficiency in the $D$ site in these two samples. This is the strongest $\mathrm{Al}$ enrichment (up to 9.15 wt. $\% \mathrm{Al}_{2} \mathrm{O}_{3}$ ) yet recorded in a chevkinite-group mineral and is in line with the reports by Harley (1994) and Hokada (2007) of large $\mathrm{Al}$ contents in the $C$ sites of Antarctic perrierites.

\section{The $D$ site}

With the exception of the two samples noted above, the $D$ site is filled with $\mathrm{Ti}$, and in all samples, $\mathrm{Ti}$ is the dominant cation at this site.
The tetrahedral site

Silicon ranges between 4 and 4.29 a.p.f.u., thus filling the tetrahedral site. The values $>4$ are probably due to minor analytical error.

\section{Nomenclature}

Given the site occupancies inferred above, none of the analysed samples is perrierite, if this mineral is understood to have dominantly $\mathrm{Fe}$ or $\mathrm{Ti}$ at the $C$ site. Instead, because $\mathrm{Al}$ turns out to be the dominant cation at this site, the mineral from all the localities studied by us could be provisionally called the Al-dominant analogue of perrierite-(Ce), as is the mineral studied by Hokada (2007). The mineral from Mt. Cronus differs further in that $\mathrm{Y}$ is dominant among $R E E+$ $\mathrm{Y}$, so it could be provisionally termed the Al-dominant analogue of perrierite-(Y).

However, this discussion leads to the question: which sites should be used to distinguish species within the chevkinite group? In recognizing 


\section{H. E. BELKIN ET AL.}

dingdaohengite-(Ce) as distinct from chevkinite(Ce), $\mathrm{Xu}$ et al. (2008) cited the $C$ site as a criterion to distinguish this species within the chevkinite group. Applying this criterion, the Aldominant analogue of perrierite-(Ce) is potentially a new species. Moreover, use of Levinson modifiers implies that the $A$ site is also a criterion, and the Al-dominant analogue of perrierite-(Y) would thus become the second potentially new species among the samples reported here. Thirdly, the distinction between rengeite and matsubaraite implies that the $B$ site has also been used as a criterion, and that the Mg-dominant Vestfold Hills mineral described by Harley (1994) is a third potentially new species, the $\mathrm{Mg}, \mathrm{Al}$-dominant analogue of perrierite-(Ce).

Table 1 lists end-member formulae for known and some potential species using the $A, B$ and $C$ sites as criteria to distinguish them; other combinations of REE, $\mathrm{Ca}, \mathrm{Sr}, \mathrm{Zr}, \mathrm{Fe}^{2+}, \mathrm{Mg}$, $\mathrm{Fe}^{3+}, \mathrm{Cr}$ and Ti could lead to a host of others, not to mention potential Y- and La-dominant endmembers (the latter was reported by Segalstad and Larsen, 1978). Moreover, the three sites do not exhaust the possibilities; there are two $A$ sites and the $D$ site. While the latter is invariably dominated by $\mathrm{Ti}$, the different $A$ sites could differ in composition.

The recently described Fe-Ti-dominant chevkinite-subgroup minerals maoniupingite-(Ce) (IMA2003-017, Shen et al., 2005) and dingdaohengite-(Ce) (IMA 2005-14, Xu et al., 2008) were introduced without properly clarifying their relationship to chevkinite-(Ce). The formula calculated from the analysis of maoniupingite(Ce) reported by Shen et al. (2005) can be expressed as a mixture of $61 \% \mathrm{Ce}_{4} \mathrm{Fe}^{2+}\left(\mathrm{Fe}_{2}^{3+}\right)$ $\mathrm{Ti}_{2} \mathrm{Si}_{4} \mathrm{O}_{22}, 22 \% \mathrm{Ca}_{4} \mathrm{Ti}\left(\mathrm{Ti}_{2}\right) \mathrm{Ti}_{2} \mathrm{Si}_{4} \mathrm{O}_{22}$ and minor amounts of other components, i.e. it is predominantly chevkinite-(Ce) as later defined for the purpose of distinguishing chevkinite-(Ce) from dingdaohengite-(Ce). The end-member formula $\mathrm{Ce}_{4} \mathrm{Fe}^{3+}\left(\mathrm{Fe}_{2}^{3+}\right) \mathrm{Ti}_{2} \mathrm{Si}_{4} \mathrm{O}_{22}$ that $\mathrm{Xu}$ et al. (2008) gave for maoniupingite- $(\mathrm{Ce})$ does not correspond to the Shen et al. (2005) electron microprobe and Mössbauer spectroscopic analysis, which we calculate to yield $0.77 \mathrm{Fe}^{2+}, 0.05 \mathrm{Mn}$ and 0.05 $\mathrm{Mg}$, almost sufficient to fill the $B$ site. Moreover, the Xu et al. (2008) end-member formula is not balanced in charge.

Our end-member formula for dingdaohengite(Ce), $\mathrm{Ce}_{4} \mathrm{Fe}^{2+}\left(\mathrm{Fe}^{2+} \mathrm{Ti}^{2} \mathrm{Ti}_{2} \mathrm{Si}_{4} \mathrm{O}_{22}\right.$, differs from $\mathrm{Ce}_{4} \mathrm{Fe}^{2+}\left(\mathrm{Ti}_{2}\right) \mathrm{Ti}_{2} \mathrm{Si}_{4} \mathrm{O}_{22}$, the ideal end-member given by Xu et al. (2008). Their ideal formula is not charge-balanced, although their empirical formula with $\mathrm{Ti}$ dominant at the $C$ site is. By invoking one of the characteristics of end-member formulae that Hawthorne (2002) recommended in defining new mineral species, viz. that an endmember may have more than one type of cation at one site 'if required by the electroneutrality principle', the formula given in Table 1 can be justified. In a chevkinite-group mineral with $R E E$ at the $A$ site, this attribute of end-member formulae means that no more than $50 \%$ of the $C$ site can be occupied by $\mathrm{Ti}$ unless its charge is balanced by a divalent cation at the site. As a result, our end-member composition does not meet the criterion of $\mathrm{Ti}$ dominance at the $C$ site cited for distinguishing dingdaohengite-(Ce) from chevkinite-(Ce); the criterion would have to be $\mathrm{Ti}, \mathrm{Fe}^{2+}$ instead.

Strontio-chevkinite is another problematic species. Miyawaki et al. (2002) re-indexed the XRD data of Haggerty and Mariano (1983) and suggested that strontio-chevkinite could be an Ferich variety of rengeite, i.e. in the perrierite subgroup. Our recalculation of the two chemical analyses reported by Haggerty and Mariano(1983) suggests that the rengeite end-member constitutes $\sim 55 \%$ of strontio-chevkinite and its $\mathrm{Ca}$ analogue (Table 1) another $10 \%$; a REE-Fe ${ }^{2+}$ end-member (Table 1) is one of the possible components making up the balance. In summary, the distinction between strontio-chevkinite and rengeite needs to be re-examined.

To resolve these issues, and the even more complicated problems in crystal structure which we have not broached here, it would be necessary to review systematically chevkinite-group nomenclature and explicitly lay out criteria and give charge-balanced end-members; only then could new species be defined in a proper manner. Such a review is best handled by a subcommittee of the Commission of New Minerals, Nomenclature and Classification, International Mineralogical Association (CNMNC IMA), and is clearly beyond the scope of the present paper.

\section{Composition of chevkinite-group minerals, rock type and nature of protoliths}

Macdonald and Belkin (2002) showed that perrierite has most commonly been recorded from mafic igneous rocks, such as anorthositic gabbro and pegmatite and K-rich volcanics of lamproitic or minette affinity, and from granodiorites and latites, where $R E E / \mathrm{Ca}$ and $\mathrm{Fe} / \mathrm{Ca}$ are 
normally low. Chevkinite and perrierite from different igneous parageneses were shown by Macdonald and Belkin (2002) to occupy discrete fields on a $\left(\mathrm{CaO}+\mathrm{MgO}+\mathrm{SrO}+\mathrm{Al}_{2} \mathrm{O}_{3}\right)-$ $\left(\Sigma \mathrm{La}_{2} \mathrm{O}_{3}-\mathrm{Sm}_{2} \mathrm{O}_{3}\right)-\mathrm{FeO} *$ plot (Fig. 7). The Eastern Ghats and Antarctic data, including the analyses by Harley (1994) and Hokada (2007), plot roughly parallel to, but displaced to the Fepoor side of, the field of perrierites from mafic and intermediate igneous rocks.

The analysed chevkinite-group minerals originated from three distinct parageneses, and their compositions reflect this. Samples 2131 and 2098A are from pegmatites containing hornblende and orthopyroxene or garnet intrusive into orthopyroxene-bearing quartzofelspathic rocks. These chevkinite-group minerals have relatively large $\mathrm{FeO}$ contents and small $\mathrm{MgO}$ and $\mathrm{Al}_{2} \mathrm{O}_{3}$ contents; their compositions plot in the field for mafic and intermediate igneous rocks (Fig. 7). Similarly, compositions of the chevkinite-group minerals in the orthopyroxene-bearing gneiss and granulite from Mt. Charles and the Fyfe Hills plot in this field. DePaolo et al. (1982) concluded that the protolith of sample 28-VII from the Fyfe Hills was a volcanic rock or a sediment consisting of immature detritus from an igneous terrane. A similar precursor is plausible for sample 2084E; i.e. these chevkinite-group minerals also did not crystallize in an aluminous environment. In contrast, the remaining samples, including that described by Hokada (2007), are highly aluminous paragneisses in which the associated minerals are relatively magnesian or aluminous: sapphirine, orthopyroxene, and sillimanite; even garnet has a relatively high $\mathrm{Mg} / \mathrm{Fe}$ ratio: $55 \%$ pyrope and $43 \%$ almandine in $2234 \mathrm{E}$ (Grew et al., 2006). Chevkinite-group minerals in these samples are notably more aluminous and their $\mathrm{Mg} / \mathrm{Fe}$ ratios greater than in the other samples analysed in this study. The Vestfold Hills chevkinite-group mineral represents an extreme in which the association in melt pools with sapphirine, spinel and enstatite approaching their

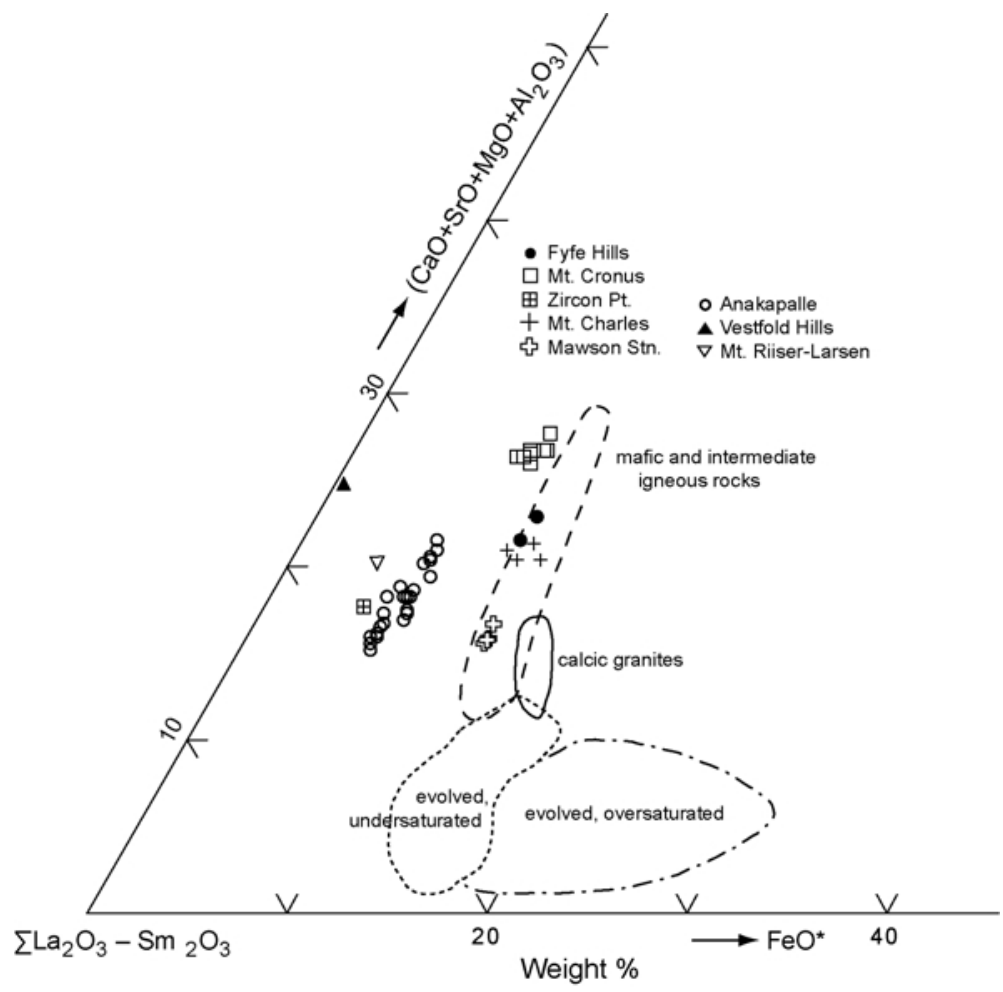

FIG. 7. Triangular plot showing the generalized fields of chevkinite and perrierite in various rock types (Macdonald and Belkin, 2002). The fields marked 'evolved, undersaturated' and 'evolved, oversaturated' are occupied only by chevkinite; the field of mafic and intermediate igneous rocks includes only perrierite. Both phases occur in the field of calcic granites. 


\section{H. E. BELKIN ET AL.}

respective $\mathrm{Mg}$ end-member compositions (Harley and Christy, 1995) results in a chevkinite-group mineral with $0.78 \mathrm{Mg}$ and only $0.05 \mathrm{Fe}$ at the $B$ site (Harley, 1994), as well as an $\mathrm{Al}_{2} \mathrm{O}_{3}$ content as high as that in our chevkinite-group minerals from paragneiss. The aluminous chevkinite-group minerals with relatively high $\mathrm{Mg} / \mathrm{Fe}$ ratio formed at temperatures possibly as high as $1000-1180^{\circ} \mathrm{C}$ at pressures ranging from $3-4$ kbar in the melt pools (Harley and Christy, 1995) to 7-10 kbar in the Napier Complex (e.g. Harley, 1998, 2008), conditions that extend the known stability range of the natural chevkinite-group minerals.

\section{Acknowledgements}

We thank G.E. Grikurov for sample 28-VII and Martin Yates for drawing our attention to the overlap of the Ce-M $M$ and $\mathrm{F}-K \alpha$ peaks. The Australian National Antarctic Research Expedition is thanked for logistics support of fieldwork during the 1977-1978 and 1979-1980 seasons, and the Indo-American Fellowship Program is thanked for support in India in 1980 and 1981. ESG's fieldwork in Antarctica was also supported by U.S. National Science Foundation grant DPP-7680957. We thank I-Ming Chou, Paul C. Hackley, Leonid Pautov, and Elena Sokolova for their helpful and constructive reviews. Any use of trade, product, or firm names is for descriptive purposes only and does not imply endorsement by the U.S. Government.

\section{References}

Asami, M., Suzuki, K., Grew, E.S. and Adachi, M. (1998) CHIME ages for granulites from the Napier complex, East Antarctica. Polar Geoscience, 11, 172-199.

Asami, M., Suzuki, K. and Grew, E.S. (2002) Chemical Th-U-total $\mathrm{Pb}$ dating by electron microprobe analysis of monazite, xenotime and zircon from the Archean Napier complex, East Antarctica: evidence for ultrahigh-temperature metamorphism at $2400 \mathrm{Ma}$. Precambrian Research, 114, 249-275.

Atrashenok, L.Ya., Avdzeyko, G.V., Klimov, A.V., Krylov, A.Ya. and Silin, Yu.I. (1967) Comparative data on absolute ages of Antarctic rocks (lead and argon methods). Akademiya Nauk SSSR Komissiya po Opredeleniyu Absolyutnogo Vozrasta Geologicheskikh Formatsii Trudy, 14, 227-229 (in Russian).

Bonatti, S. and Gottardi, G. (1966) Un caso di polimorfismo a strati in sorosilicati: perrierite chevkinite. Periodico di Mineralogia, 35, 69-91.

Bose, S., Fukuoka, M., Sengupta, P. and Dasgupta, S. (2000) Evolution of high-Mg-Al granulites from Sunkarametta, Eastern Ghats, India: evidence for a lower crustal heating-cooling trajectory. Journal of Metamorphic Geology, 18, 223-240.

Carlier, G. and Lorand, J.P. (2008) Zr-rich accessory minerals (titanite, perrierite, zirconolite, baddeleyite) record strong oxidation associated with magma mixing in the south Peruvian potassic province. Lithos, 104, 54-70.

Crisp, R.S. (1991) Wavelengths of emission lines in the $\mathrm{M}$ spectrum of ${ }^{49}$ In metal in the range of $12-265 \mathrm{AA}$. Journal of Physics: Condensed Matter, 3, 927-932.

DePaolo, D.J., Manton, W.I., Grew, E.S. and Halpern, M. (1982) Sm-Nd, Rb-Sr and U-Th-Pb systematics of granulite facies rocks from Fyfe Hills, Enderby Land, Antarctica. Nature, 298, 614-618.

Grew, E.S. (1982) Sapphirine, kornerupine, and sillimanite + orthopyroxene in the charnockitic region of South India. Journal of the Geological Society of India, 23, 469-505.

Grew, E.S. (1998) Boron and beryllium minerals in granulite-facies pegmatites and implications of beryllium pegmatites for the origin and evolution of the Archean Napier Complex of East Antarctica. Memoirs of the National Institute of Polar Research, Special Issue, 53, 74-92.

Grew, E.S. and Manton, W.I. (1979a) Archean rocks in Antarctica: 2.5-billion-year uranium-lead ages of pegmatites in Enderby Land. Science, 206, 443-445.

Grew, E.S. and Manton, W.I. (1979b) Geochronologic studies in East Antarctica: Age of a pegmatite in Mawson charnockite. Antarctic Journal of the United States, 14 (5), 2-3.

Grew, E.S. and Manton, W.I. (1986) A new correlation of sapphirine granulites in the Indo-Antarctic metamorphic terrain: late Proterozoic dates from the Eastern Ghats Province of India. Precambrian Research, 33, 123-137.

Grew, E.S., Yates, M.G., Barbier, J., Shearer, C.K., Sheraton, J.W., Shiraishi, K. and Motoyoshi, Y. (2000) Granulite-facies beryllium pegmatites in the Napier Complex in Khmara and Amundsen Bays, western Enderby Land, East Antarctica. Polar Geoscience, 13, 1-40.

Grew, E.S., Yates, M.G., Shearer, C.K., Hagerty, J.J., Sheraton, J.W. and Sandiford, M. (2006) Beryllium and other trace elements in paragneisses and anatectic veins of the ultrahigh-temperature Napier Complex, Enderby Land, East Antarctica: the role of sapphirine. Journal of Petrology, 47, 859-882.

Grew, E.S., Hålenius, U. Pasero, M. and Barbier, J. (2008) Recommended nomenclature for the sapphirine and surinamite groups (sapphirine super- 
group). Mineralogical Magazine, 72, 839-876.

Haggerty, S.E. and Mariano, A.N. (1983) Strontianloparite and strontio-chevkinite: Two new minerals in rheomorphic fenites from the Paraná Basin carbonatites, South America. Contributions to Mineralogy and Petrology, 84, 365-381.

Halpin, J.A., Gerakiteys, C.L., Clarke, G.L., Belousova, E.A. and Griffin, W.L. (2005) In-situ U-Pb geochronology and $\mathrm{Hf}$ isotope analyses of the Rayner Complex, east Antarctica. Contributions to Mineralogy and Petrology, 148, 689-706.

Harley, S.L. (1994) Mg-Al yttrian zirconolite in a partially melted sapphirine granulite, Vestfold Hills, East Antarctica. Mineralogical Magazine, 58, 259-269.

Harley, S. (1998) On the occurrence and characterization of ultrahigh-temperature crustal metamorphism. Pp. 81-107 in: What Drives Metamorphism and Metamorphic Reactions? (P.J. Treloar and P.J. O'Brien, editors). Special Publications, 138, The Geological Society, London.

Harley, S. (2008) Refining the $P-T$ records of UHT crustal metamorphism. Journal of Metamorphic Geology, 26, 125-154.

Harley, S.L. and Christy, A.G. (1995) Titanium-bearing sapphirine in a partially melted aluminous granulite xenolith, Vestfold Hills, Antarctica: geological and mineralogical implications. European Journal of Mineralogy, 7, 637-653.

Hawthorne, F.C. (2002) The use of end-member chargearrangements in defining new mineral species and heterovalent substitutions in complex minerals. The Canadian Mineralogist, 40, 699-710.

Hokada, T. (2007) Perrierite in sapphirine-quartz gneiss: geochemical and geochronological features and implications for accessory-phase paragenesis of UHT metamorphism. Journal of Mineralogical and Petrological Sciences, 102, 44-49.

Johnson, G.G., Jr. and White, E.W. (1970) X-ray Emission Wavelengths and keV Tables for Nondestructive Analysis. American Society for Testing and Materials Data Series DS 46, Philadelphia, Pennsylvania, USA.

Kamenev, Ye.N. (1972) Geological structure of Enderby Land. Pp. 579-583 in: Antarctic Geology and Geophysics (R.J. Adie, editor). Universitetsforlaget, Oslo.

Lima-de-Faria, J. (1962) Heat treatment of chevkinite and perrierite. Mineralogical Magazine, 33, 42-47.

Macdonald, R. and Belkin, H.E. (2002) Compositional variation in minerals of the chevkinite group. Mineralogical Magazine, 66, 1075-1098.

Miyawaki, R., Matsubara, S. and Miyajima, H. (2002) The crystal structure of rengeite, $\mathrm{Sr}_{4} \mathrm{ZrTi}_{4}\left(\mathrm{Si}_{2} \mathrm{O}_{7}\right)_{2} \mathrm{O}_{8}$. Journal of Mineralogical and Petrological Sciences, 97, 7-12.
Parodi, G.C., Della Ventura, G., Montana, A. and Raudsepp, M. (1994) Zr-rich non metamict perrierite-(Ce) from holocrystalline ejecta in the Sabatini volcanic complex (Latium, Italy). Mineralogical Magazine, 58, 607-613.

Sarkar, S., Dasgupta, S. and Fukuoka, M. (2003) Petrological evolution of a suite of spinel granulites from Vizianagram, Eastern Ghats Belt, India, and genesis of sapphirine-bearing assemblages. Journal of Metamorphic Geology, 21, 899-913.

Segalstad, T.V. and Larsen, A.O. (1978) Chevkinite and perrierite from the Oslo region, Norway American Mineralogist, 63, 499-505.

Sengupta, P., Sen, J., Dasgupta, S., Raith, M., Bhui, U.K. and Ehl, J. (1999) Ultra-high temperature metamorphism of metapelitic granulites from Kondapalle, Eastern Ghats Belt: Implications for the Indo-Antarctic correlation. Journal of Petrology, 40, 1065-1087.

Shen, G., Yang, G. and Xu, J. (2005) Maoniupingite(Ce): a new rare-earth mineral from the Maoniuping rare-earth deposit in Mianning, Sichuan. Sedimentary Geology and Tethyan Geology (Chenji yu Tetisi Dizhi), 25, 210-216 [in Chinese with English abstract].

Sheraton, J.W. (1982) Origin of charnockitic rocks of MacRobertson Land. Pp. 489-497 in: Antarctic Geoscience (C. Craddock, editor). University of Wisconsin Press, Madison, USA.

Sheraton, J.W., Tingey, R.J., Black, L.P, Offe, L.A. and Ellis, D.J. (1987) Geology of an unusual Precambrian high-grade metamorphic terrane Enderby Land and western Kemp Land, Antarctica. Department of Resources and Energy, Bureau of Mineral Resources, Geology and Geophysics Bulletin, 223, 1-51.

Shimazaki, H., Yang, Z., Miyawaki, R. and Shigeoka, M. (2008) Scandium-bearing minerals in the Bayan Obo Nb-REE-Fe deposit, Inner Mongolia, China. Resource Geology, 58, 80-86.

Sokolova, E., Hawthorne, F.C., Della Ventura, G. and Kartashov, P.M. (2004) Chevkinite-(Ce): crystal structure and the effect of moderate radiationinduced damage on site-occupancy refinement. The Canadian Mineralogist, 42, 1013-1025.

Song, R., Ding, K. and Li, Z. (1999) Site occupancies of iron in saimaite and chevkinite. Chinese Science Bulletin, 44, 2274-2276.

Sun, S-S. and McDonough, W.F. (1989) Chemical and isotopic systematics of oceanic basalts: implications for mantle composition and processes. Pp. 313-345 in: Magmatism in the Ocean Basins (A.D. Saunders and M.J. Norry, editors). Special Publications, 42, The Geological Society, London.

van Bergen, M.J. (1984) Perrierite in siliceous lavas from Mt Amiata, central Italy. Mineralogical 
Magazine, 48, 553-556.

Wendt, M. and Christ, B. (1985) The relative intensity of M $\zeta$-lines. Crystal Research and Technology, 20, $1443-1449$.

Xu, J., Yang, G., Li, G., Wu, Z. and Shen, G. (2008) Dingdaohengite-(Ce) from the Bayan Obo REE-NbFe Mine, China: Both a true polymorph of perrierite(Ce) and a titanic analog at the $C 1$ site of chevkinite subgroup. American Mineralogist, 93, 740-744.

Yakovenchuk, V.N., Ivanyuk, G.Yu., Pakhomovsky, Ya.A. and Menshikov, Yu.P. (2005) Khibiny. (F. Wall, editor). Laplandia Minerals, Apatity, in association with the Mineralogical Society of Great Ireland and Ireland, $448 \mathrm{pp}$.

Young, D.N. and Black, L.P. (1991) U-Pb zircon dating of Proterozoic igneous charnockites from the Mawson Coast, East Antarctica. Antarctic Science, 3, 205-216.

Young, D.N., Zhao, J.-X., Ellis, D.J. and McCulloch, M.T. (1997) Geochemical and Sr-Nd isotopic mapping of source provinces for the Mawson charnockites, East Antarctica: implications for Proterozoic tectonics and Gondwana reconstruction. Precambrian Research, 86, 1-19. 